Journal of Applied Finance \& Banking, Vol. 10, No. 6, 2020, 175-202

ISSN: 1792-6580 (print version), 1792-6599(online)

https://doi.org/10.47260/jafb/1069

Scientific Press International Limited

\title{
The Impact of Innovation on Banking Performance: \\ Evidence from Lebanese Banking Sector
}

\author{
Fatima Chalabi'
}

\begin{abstract}
This study examines the impact of innovation on performance of the Lebanese banks during 7 years period from 2009 to 2015. Based on a sample of seventeen Lebanese owned commercial banks, a Weighted Least Squares model was employed to investigate the relationship between two banking innovations, namely mobile banking and investment in computer software and banks' performance as measured by Return-On-Assets and Return-On-Equity. Four control variables were included in the study specifically bank's capitalization, cost efficiency, asset quality and bank's size. The findings of the study showed that the two innovations studied have both significant but opposite impact on banks' performance.
\end{abstract}

Keywords: Innovation, Mobile banking, Computer software, Banking performance, Lebanese banking sector, Lebanese owned commercial banks, Weighted Least Squares.

${ }^{1}$ Lebanese International University, Department of Banking and Finance.

Article Info: Received: August 30, 2020. Revised: September 16, 2020.

Published online: September 21, 2020. 


\section{Introduction}

Innovation is the application of better solutions that meet new requirements, in articulated or existing market needs. This is accomplished through more effective products, processes, services, technologies, or ideas that are readily available to markets, governments and society (Boston Consulting Group, 2009). Technological innovations affect banking sector as much as other economic sectors. DeYoung (2001) has forecasted that technological progress will destroy the models used in developing and delivering services in banks and will replace them with new and original ones.

In Lebanon, the banking sector is characterized by its high involvement in innovation. Most of Lebanese banks have high standards of excellence in terms of technology, high tech facilities, customer services and customer orientation where all transactions and operations are computerized (Sarji, 2017). Lebanese banking sector is always developing new means of payments and remote banking systems that facilitates banking transactions (ABL, 2014). They have offered new delivery channels like Point Of Sale (POS) terminals, mobile banking and Automated Teller Machines (ATMs). The number of ATMs has reached 1,597 in 2014 distributed all around Lebanese territory (ABL, 2014). Moreover, according to World bank (2017), the number of ATMs per 100,000 adults in Lebanon is higher than the average in middle eastern countries between 2009 and 2014 (See figure 1 below).

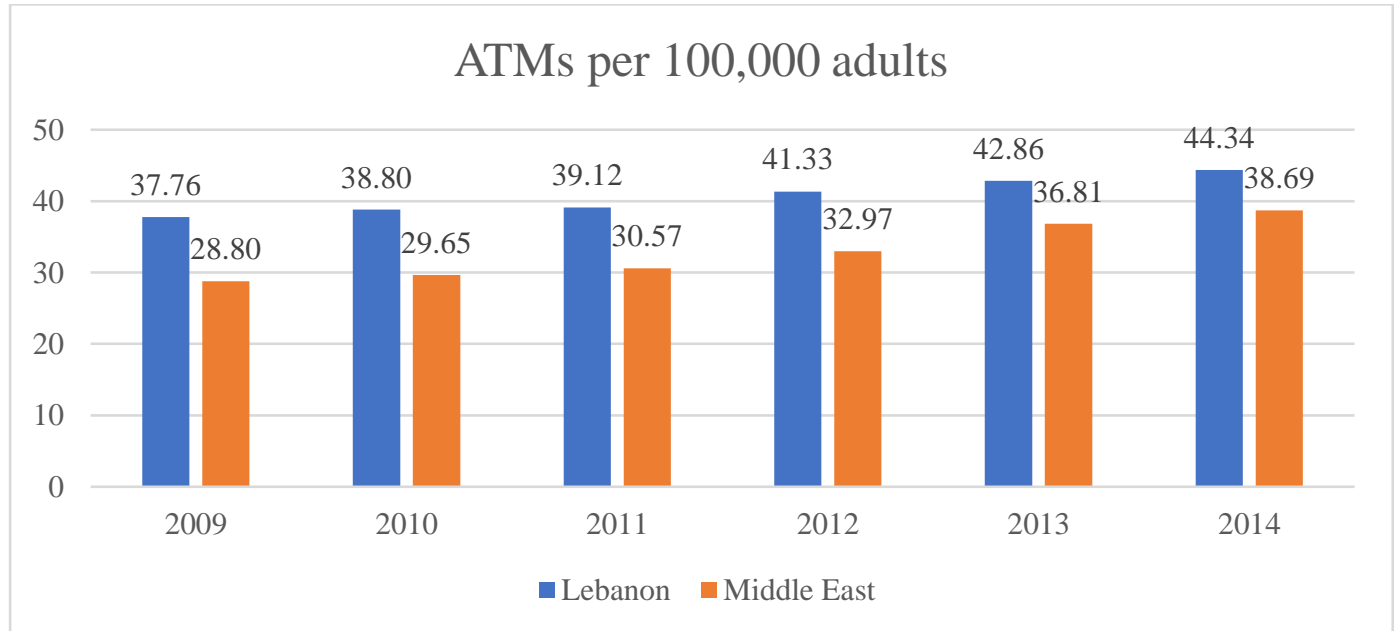

Figure 1 - Number of ATMs per 100,000 adults: Comparison between Lebanon and the Middle East.

Source: World Bank (2017)

Furthermore, the number of cards issued by banking system in Lebanon has reached 2.4 million cards in 2014 (ABL, 2014). Finally, according to BLOMINVEST (2016), 93\% of Lebanese commercial banks offer digital banking services while only $7 \%$ of banks in Lebanon do not offer these services. 
Despite the fact that Lebanese banking sector is highly affected by technological progress, few researchers have studied the impact of innovation on banking performance (Sujud and Hashem, 2017) compared to the number of researchers that have studied the same topic worldwide (Beccalli, 2007; Onay et al., 2008; AlSamadi and Al-Wabel, 2011; Akhisar et al., 2015). These researchers have accused technological advances of the decreased performance encountered by many banks around the world during the global financial crisis of 2007-2009.

The results of the different studies were contradictory. Some researchers have found that banking innovations have positive impact on bank's performance (Onay et al., 2008; Kithaka, 2014; Ben Romdhane, 2013), while others have showed that banking innovations negatively affect bank's performance (Al-Samadi and AlWabel, 2011). In addition, there are some studies that haven't found any significant association between innovation and banking performance (Khrawish and Al-Sa'di, 2011; Samout, 2016).

Consequently, there is a necessity to carry out a study in Lebanese banking sector that examines the relationship between financial innovations and banks' performance. Thus, the main objective of this study is to investigate the impact of different banking innovations, namely mobile banking and investment in computer software on Lebanese banks' performance. In order to achieve this purpose, a Weighted Least Squares regression was employed using unbalanced panel data from 17 Lebanese owned commercial banks from 2009-2015.

This research first, reviews the theoretical and empirical literature related to innovation and banks' performance. Second, it presents the research methodology employed to attain the objective of the study. Third, it provides the findings of the research and discusses them. Finally, it concludes.

\section{The impact of Innovation on Banking Performance: Theoretical and Empirical Evidence}

Many researchers have examined the relationship between innovation and banks' performance theoretically and empirically. This study provides first, the Solow Paradox theory. Second, it discusses the impact of mobile banking and investment in computer software on banks performance. And finally, it provides an empirical evidence.

\subsection{Solow Paradox Theory}

The Solow paradox also called productivity paradox is originated by Robert Solow, a Nobel Prize winner in economics. During 1970s and 1980s, the United States (US) have witnessed a slowdown of productivity growth. The average labor productivity between 1947 and 1973 was 2.4\% compared to $1 \%$ between 1973 and 1988 (Federal Reserve Bank of Richmond, 1989). This decrease in productivity was observed in spite of the huge development in Information Technology (IT) investment. Accordingly, Solow (1987), as cited by Ben Romdhane (2013), has stated during his Nobel speech that "you can see the computer age everywhere but in the 
productivity statistics". Thus, the investment in IT has no impact on productivity. As result, many academic researchers have failed to prove any significance between IT investment and the increase in overall productivity in US (Yosri, 1992; Weill, 1992). Significant productivity can be attributed to transactional types of IT, but there are no gains associated with strategic systems or IT investment (Weill, 1992). Many studies tried to explain the productivity paradox (Brynjolfsson, 1993). According to Brynjolfsson (1993), there are 4 categories to group the various explanations proposed: (1) Mismeasurement of outputs and inputs, (2) Lags due to learning and adjustment, (3) Redistribution and dissipation of profits, and (4) Mismanagement of information and technology.

Some other studies have resolved the productivity paradox, by proving that there is a delay between IT investment and productivity jump (Dewan and Kraemer, 1998). IT investments are productive, but their benefits are realized only after a lag period, during which complementary capital investments must be developed to allow for the use of computers to their full potential (David, 1990). Finally, many economists do not approve the existence of a productivity paradox. They view it more as a series of unwanted assumptions about the impact of IT on productivity than a paradox (David, 1990).

\subsection{Mobile Banking and Financial Performance}

Mobile banking, as previously defined, is a form of innovation that is used to make transactions through bank application downloaded on smart phones that are transformed into pocket banks. It refers to providing financial and banking services with the help of mobile telecommunication devices. These services are performed distantly from traditional branches. As a result, mobile banking could be denoted as branchless banking. Some authors consider mobile banking as an appendage of ebanking (Abaenewe et al., 2013), while others consider it as a separate delivery channel (Mwange, 2013)

Banking services that could be provided by mobile banking are in general: checking accounts balances, checking new products and services, simulating loans, monitoring transactions, locating traditional branches and ATMs, transferring funds, converting currencies, paying bills and much more services. The diversification of these services depends on the degree of banks' involvement in innovation.

Many researchers have reviewed the impact of mobile banking on banks financial performance. As previously mentioned, the Solow paradox is the main theory used to explain the impact of mobile banking, and generally of IT investment, on banks productivity and performance. In many studies, Solow paradox has been rejected. According to Mwange (2013), mobile banking leads to higher financial performance through higher operational efficiency. This latter is achieved through conducting targeted marketing campaigns based on tracking customers' preferences. In consequence, bank's expenses in terms of marketing will decrease. Moreover, it is achieved through decreasing staff numbers since less face to face transactions are performed. Wishart (2006) stated that mobile banking could lead to higher customer 
loyalty, increased market shares and declining operational costs. According to Tiwari et al. (2006), 15\% of banks customers would change their banks if it fails to provide mobile banking services in Germany. Mania (2012) has stated that mobile banking positively affect financial performance since banks could serve a larger number of customers within a shorter period of time. This positive relationship was supported by many researchers at different significance levels (Abaenewe et al., 2013; Kithaka, 2014; Kathuo et al., 2015). Paradoxically, in line with Solow paradox, other researchers could not find any significant relationship between mobile banking and bank's financial performance (Alber, 2010; Mutua, 2013). According to Alber (2010), this insignificant relationship is attributed to 2 main reasons. First, high perceived risk in mobile banking and low confidentiality. And second, low knowledge about different services in mobile banking. Based on the previous discussion, this research considers that mobile banking positively affects banking performance.

\section{H1: Mobile banking has a significant positive impact on bank's performance.}

\subsection{Investment in Computer Software and Financial Performance}

Computer software is an intangible asset. It is an essential component of IT in banks, which includes mainly hardware, software and IT services. The impact of investment in computer software on bank's financial performance has been widely studied in literature. Researchers have either studied the impact of IT components together on financial performance (Jalal-karim and Hamdan, 2010) or examined the effect of different IT components on bank's financial performance separately (Beccalli, 2007; Ben Romdhane, 2013).

Beccalli (2007) has found evidence of Solow paradox theory when studying the impact of IT on financial performance of European Union (EU) banks. She found that IT investment has no clear effect on bank's performance measures (Return-OnAssets (ROA), Return-On-Equity (ROE) and efficiency). In conclusion, she recommended banks to decrease their investment in both hardware and software in order to increase their financial performance. Many other researchers have found support of this theory (Licht and Moch, 1999; Oluwagbemi et al., 2011). However, Ben Romdhane (2013) have contradicted the Solow paradox and found evidence that IT investment in terms of hardware, software and IT services positively affect banks' efficiency. Also, both Lichtenberg (1995) and Prasad and Harker (1997) studies have contradicted this paradox. Chen and $\mathrm{Zu}$ (2004) have stressed on the necessity of IT investment for a better performance. Furthermore, Markus and Soh (1993) have supported the Solow paradox in small banks, while they found a contradiction of this paradox in large banks. Based on this, computer software is expected to positively affect banking performance.

H2: Investment in computer software has a significant positive impact on bank's performance. 


\subsection{Empirical Studies: Impact of Innovation on Banking Performance}

The studies that have examined the impact of innovation on banks' performance are numerous. This research divides them based on the sample region as follow: (1) international and (2) Middle East and North Africa (MENA) studies. Tables 1 and 2 below represents these two types respectively. 
Table 1: International Evidence: The impact of innovation on bank's performance

\begin{tabular}{|c|c|c|}
\hline Study & & Details \\
\hline \multirow[t]{5}{*}{ Beccalli (2007) } & Country & European countries (Germany, France, Spain, Italy, UK) \\
\hline & Purpose & The impact of different IT investments on banks' performance \\
\hline & Methodology & $\begin{array}{l}\text { Sample: } 737 \text { banks } \\
\text { Period:1993-2000 } \\
\text { Method(s): Ordinary Least Squares \&Two-Stage Least Squares }\end{array}$ \\
\hline & Variables & $\begin{array}{l}\text { Dependent: } \\
\text { - ROA; ROE; Cost efficiency; Profit efficiency } \\
\text { Independent: } \\
\text { - IT to equity; Computer hardware and software investments; IT } \\
\text { services (consulting, training, implementation and support) } \\
\text { investment }\end{array}$ \\
\hline & Results & $\begin{array}{l}\text { IT to equity: } \\
\text { - Significant negative impact on short term ROA and ROE } \\
\text { - Significant positive impact on efficiency } \\
\text { Computer hardware and software investments: } \\
\text { - Negative impact on ROA, ROE and profit efficiency } \\
\text { IT services: } \\
\text { - Positive impact on ROA, ROE and profit efficiency }\end{array}$ \\
\hline \multirow[t]{5}{*}{ Onay et al. (2008) } & Country & Turkey \\
\hline & Purpose & The impact of internet banking on banks' performance \\
\hline & Methodology & $\begin{array}{l}\text { Sample: } 14 \text { commercial and saving banks } \\
\text { Period: } 1996-2005 \\
\text { Method(s): Generalized Least Squares }\end{array}$ \\
\hline & Variables & $\begin{array}{l}\text { Dependent: } \\
\text { - ROA; ROE; Return on financial intermediation margin. } \\
\text { Independent: } \\
\text { - Presence of internet banking; Deposits to total assets } \\
\text { Percentage change in GDP per capita; Loans to total assets; } \\
\text { Bank crisis; Lending rate. }\end{array}$ \\
\hline & Results & $\begin{array}{l}\text { Internet banking: } \\
\text { - Positive impact on all performance measures. } \\
\text { Deposits to total assets and percentage change in GDP per } \\
\text { capita: } \\
\text { - Positive impact on all performance measures } \\
\text { Loans to total assets and bank crisis: } \\
\text { - Negative impact on all performance measures } \\
\text { Lending rate: } \\
\text { - Negative impact on ROA } \\
\text { - Positive impact on ROE and return on the financial } \\
\text { intermediation margin }\end{array}$ \\
\hline \multirow{2}{*}{$\begin{array}{c}\text { European Central } \\
\text { Bank (2009) }\end{array}$} & Country & 27 European countries \\
\hline & Purpose & $\begin{array}{l}\text { The relationship between bank performance and retail payment } \\
\text { business }\end{array}$ \\
\hline
\end{tabular}




\begin{tabular}{|c|c|c|}
\hline & Methodology & $\begin{array}{l}\text { Sample: } 3,370 \text { commercial, saving and cooperative banks } \\
\text { Period: } 2000-2007 \\
\text { Method(s): Multivariate regression }\end{array}$ \\
\hline & Variables & $\begin{array}{l}\text { Dependent: } \\
\text { - ROA; ROE; Profit efficiency; Cost efficiency. } \\
\text { Independent: } \\
\text { - Log of number of transactions to population; Log of number } \\
\text { of ATMs to total population; Log of number of retail payment } \\
\text { offices to population; Economic growth. } \\
\text { Control: } \\
\text { - Bank risk; Bank stability; Industry concentration; Percentage } \\
\text { of paper-based retail payment instruments (checks). }\end{array}$ \\
\hline & Results & $\begin{array}{l}\text { Log of number of transactions to population and Log of number } \\
\text { of ATMs to total population: } \\
\text { - Positive impact on all performance measures } \\
\text { Log of number of retail payment offices to population: } \\
\text { - Not significant with all performance measures. }\end{array}$ \\
\hline \multirow[t]{5}{*}{ Mwange (2011) } & Country & Kenya \\
\hline & Purpose & The impact of mobile banking on banks' performance \\
\hline & Methodology & $\begin{array}{l}\text { Sample: } 25 \text { commercial banks } \\
\text { Period: } 2008-2012 \\
\text { Method(s): Multiple regression }\end{array}$ \\
\hline & Variables & $\begin{array}{l}\text { Dependent: } \\
\text { - ROA } \\
\text { Independent: } \\
\text { - Cost of investment in mobile banking; Number of customers } \\
\text { registered on mobile banking; Number of mobile banking } \\
\text { transactions. }\end{array}$ \\
\hline & Results & $\begin{array}{l}\text { Cost of investment in mobile banking and number of mobile } \\
\text { banking transactions: } \\
\text { - Positive impact on ROA } \\
\text { Number of customers registered on mobile banking: } \\
\text { - Negative impact on ROA }\end{array}$ \\
\hline \multirow[t]{5}{*}{ Kithaka (2014) } & Country & Nigeria \\
\hline & Purpose & The impact of mobile banking on banks' performance \\
\hline & Methodology & $\begin{array}{l}\text { Sample: } 43 \text { commercial banks } \\
\text { Period: } 2009-2013 \\
\text { Method(s): Multiple regression }\end{array}$ \\
\hline & Variables & $\begin{array}{l}\text { Dependent: } \\
\text { - ROA; ROE. } \\
\text { Independent: } \\
\text { - Annual amount of money moved through mobile banking; } \\
\text { Number of users of mobile banking; Equity to assets ratio; } \\
\text { Loans loss provision to total loans ratio; Loans to assets ratio; } \\
\text { Operating cost to total income ratio. }\end{array}$ \\
\hline & Results & All variables: \\
\hline
\end{tabular}




\begin{tabular}{|c|c|c|}
\hline & & - Positive impact on all performance measures. \\
\hline \multirow{5}{*}{$\begin{array}{l}\text { Akhisar et } a l . \\
(2015)\end{array}$} & Country & 23 developed and developing countries \\
\hline & Purpose & The impact of innovation on banks' performance \\
\hline & Methodology & $\begin{array}{l}\text { Period: } 2005-2013 \\
\text { Method(s): Generalized Method of Moments }\end{array}$ \\
\hline & Variables & $\begin{array}{l}\text { Dependent: } \\
\text { - ROA; ROE. } \\
\text { Independent: } \\
\text { - Number of cards issued by banks; Number of POS terminals; } \\
\text { Number of ATMs to number of branches ratio; Number of } \\
\text { customers using internet banking. }\end{array}$ \\
\hline & Results & $\begin{array}{l}\text { Number of customers using internet banking and number of POS } \\
\text { terminals: } \\
\text { - Negative impact on all performance measures. } \\
\text { Number of cards issued by banks and number of ATMs to number } \\
\text { of branches: } \\
\text { - Positive impact on all performance measures }\end{array}$ \\
\hline
\end{tabular}

Table 2: MENA Evidence: The impact of innovation on bank's performance

\begin{tabular}{|c|c|c|}
\hline Study & \multicolumn{2}{|r|}{ Details } \\
\hline \multirow{5}{*}{$\begin{array}{l}\text { Jalal-karim and } \\
\text { Hamdan (2010) }\end{array}$} & Country & Jordan \\
\hline & Purpose & The impact of IT on banks' performance \\
\hline & Methodology & $\begin{array}{l}\text { Sample: } 15 \text { listed banks } \\
\text { Period:2003-2007 } \\
\text { Method(s): Pooled Least Squares }\end{array}$ \\
\hline & Variables & $\begin{array}{l}\text { Dependent: } \\
\text { - ROE; Earnings Per Share (EPS); Market Value Added (MVA); } \\
\text { ROA; Net Profit Margin (NPM). } \\
\text { Independent: } \\
\text { - Investment in software; Investment in hardware; Presence of } \\
\text { phone banking; Presence of internet banking; Presence of SMS } \\
\text { banking; Presence of cyber branches; Number of ATMs. } \\
\text { Control: } \\
\text { - Bank's size; Deposits to assets; Credits to assets. }\end{array}$ \\
\hline & Results & $\begin{array}{l}\text { ROE model: } \\
\text { - Insignificant } \\
\text { EPS, MVA, ROA and NPM models: } \\
\text { - Highly significant }\end{array}$ \\
\hline Alber (2011) & Country & Saudi Arabia \\
\hline & Purpose & The impact of banking expansion. \\
\hline & Methodology & $\begin{array}{l}\text { Sample: } 6 \text { banks } \\
\text { Period:1998-2007 } \\
\text { Method(s): Regression analysis }\end{array}$ \\
\hline & Variables & Dependent: \\
\hline
\end{tabular}




\begin{tabular}{|c|c|c|}
\hline & & $\begin{array}{l}\text { - Actual ROA over best ROA ratio; Actual ROE over best ROE } \\
\text { ratio; Actual Return-On-Capital (ROC) over best ROC ratio. } \\
\text { Independent: } \\
\text { - Number of branches; Number of ATMs; Number of POS } \\
\text { machines; Presence of phone banking; Presence of computer } \\
\text { banking; Presence of mobile banking. }\end{array}$ \\
\hline & Results & $\begin{array}{l}\text { Number of branches: } \\
\text { - Negative impact on ROE ratio } \\
\text { - Insignificant with the other two ratios } \\
\text { Number of ATMs: } \\
\text { • Negative impact on all measures } \\
\text { Phone banking: } \\
\text { - Positive impact on all measures } \\
\text { Number of POS, the presence of both computer and mobile } \\
\text { banking: } \\
\text { - Insignificant impact on all measures }\end{array}$ \\
\hline \multirow{5}{*}{$\begin{array}{l}\text { Al-Samadi and Al- } \\
\text { Wabel (2011) }\end{array}$} & Country & Jordan \\
\hline & Purpose & The impact of innovation on banks' performance \\
\hline & Methodology & $\begin{array}{l}\text { Sample: } 15 \text { commercial banks } \\
\text { Period:2000-2010 } \\
\text { Method(s): Ordinary Least Squares }\end{array}$ \\
\hline & Variables & $\begin{array}{l}\text { Dependent: } \\
\text { - ROE } \\
\text { Independent: } \\
\text { - Presence of e-banking services; Equity to assets; } \\
\quad \text { Nonperforming loans to total loans; Natural log of total assets; } \\
\text { Loans to deposits; Operating costs to total assets; GDP growth; } \\
\text { Inflation rate. } \\
\end{array}$ \\
\hline & Results & $\begin{array}{l}\text { Presence of e-banking, inflation rate and loans to deposits: } \\
\text { - Negative impact on ROE } \\
\text { Natural log of total assets, nonperforming loans and GDP } \\
\text { growth: } \\
\text { - Positive impact on ROE } \\
\text { Equity to assets and operating costs to total assets: } \\
\text { - Insignificant impact on ROE }\end{array}$ \\
\hline
\end{tabular}




\begin{tabular}{|c|c|c|}
\hline \multirow{5}{*}{$\begin{array}{l}\text { Ben Romdhane } \\
\text { (2013) }\end{array}$} & Country & Tunis \\
\hline & Purpose & The impact of IT on banks' performance \\
\hline & Methodology & $\begin{array}{l}\text { Sample: } 15 \text { commercial banks } \\
\text { Period:1998-2009 } \\
\text { Method(s): Standard Stochastic Frontier Approach }\end{array}$ \\
\hline & Variables & $\begin{array}{l}\text { Dependent: } \\
\text { - Cost efficiency } \\
\text { Independent: } \\
\text { - Technology investment (hardware and software, training and } \\
\text { maintenance) } \\
\text { Control: } \\
\text { - Net interest income to GDP ratio; Log of total assets; } \\
\text { Outstanding debts to total loans. }\end{array}$ \\
\hline & Results & $\begin{array}{l}\text { Investment in IT and log of total assets: } \\
\text { - Positive impact on cost efficiency. } \\
\text { Outstanding debts to total loans: } \\
\text { - Positive impact on cost efficiency. } \\
\text { Net interest income to GDP ratio: } \\
\text { - Insignificant impact on cost efficiency. }\end{array}$ \\
\hline \multirow[t]{5}{*}{ Samout (2016) } & Country & Tunis \\
\hline & Purpose & The impact of financial innovation on banks' performance \\
\hline & Methodology & $\begin{array}{l}\text { Sample: } 11 \text { commercial banks } \\
\text { Period: } 2005-2014 \\
\text { Method(s): Regression analysis }\end{array}$ \\
\hline & Variables & $\begin{array}{l}\text { Dependent: } \\
\text { - ROE } \\
\text { Independent: } \\
\text { - Volume of financial resources; Level of diversification; Level } \\
\text { of competition; Bank's size. }\end{array}$ \\
\hline & Results & $\begin{array}{l}\text { Volume of financial resources and level of competition: } \\
\text { - Insignificant impact on performance. } \\
\text { Bank's size and diversification: } \\
\text { - Positive impact on performance }\end{array}$ \\
\hline \multirow{4}{*}{$\begin{array}{l}\text { Sujud and Hashem } \\
\text { (2017) }\end{array}$} & Country & Lebanon \\
\hline & Purpose & $\begin{array}{l}\text { The impact of innovation on banks' profitability and } \\
\text { performance }\end{array}$ \\
\hline & Methodology & $\begin{array}{l}\text { Sample: } 200 \text { senior managers from different banks' departments. } \\
\text { Method(s): 5-point Likert scale questionnaire; Regression } \\
\text { analysis }\end{array}$ \\
\hline & Variables & $\begin{array}{l}\text { Dependent: } \\
\text { - Profitability; ROA } \\
\text { Independent: } \\
\text { - ATMs; Credit and debit cards; Electronic funds transfer; } \\
\text { Mobile banking; Internet banking; POS terminals }\end{array}$ \\
\hline
\end{tabular}




\begin{tabular}{|c|c|c|}
\hline & Results & $\begin{array}{l}\text { ATMs and POS terminals: } \\
\text { - Insignificant impact on profitability and ROA } \\
\text { Credit and debit cards: } \\
\text { - Insignificant impact on profitability } \\
\text { - Positive impact on ROA } \\
\text { Electronic funds transfer: } \\
\text { - Positive impact on profitability } \\
\text { - Insignificant impact on ROA } \\
\text { Mobile banking: } \\
\text { - Eliminated in profitability model due to multicollinearity } \\
\text { - Insignificant impact on ROA } \\
\text { Internet banking: } \\
\text { - Insignificant impact on profitability } \\
\text { - Eliminated in ROA model due to multicollinearity }\end{array}$ \\
\hline
\end{tabular}

\section{Research Methodology}

The research methodology defines the process used to collect data for the empirical study. It is divided into four parts. The first presents the target population and sample. The second indicates the data sources. The third specifies how variables are measured. The last discusses the analysis techniques used.

\subsection{Target Population and Sample}

According to the Lebanese central bank database, there are 49 commercial banks in Lebanon. Based on their ownership, they could be divided into four groups: 32 Lebanese owned banks, 7 mixed (Lebanese and Arab) owned, 7 only Arab owned and 3 foreign owned banks. The population of this study is the Lebanese owned commercial banks. Foreign, Arab and mixed owned banks were excluded to ensure uniformity of the sample.

A non-probability sampling was used in order to select 17 banks. As a result, the sample represents $53.125 \%$ (17/32) of the total population. Other Lebanese owned banks were excluded due to lack of information in their annual reports. The total assets of the sample represent $88.78 \%$ of the total assets of Lebanese owned banks in 2015. Accordingly, the sample size is appropriate to represent Lebanese owned commercial banks. 
Table 3: Sample of the Lebanese commercial banks.

\begin{tabular}{|l|c|c|c|}
\hline \multicolumn{1}{|c|}{ Banks } & $\begin{array}{c}\text { List of } \\
\text { Abbreviation }\end{array}$ & $\begin{array}{c}\text { Frequency } \\
\text { of } \\
\text { observation }\end{array}$ & \% of observation \\
\hline Audi Private Bank S.A.L & Audi & 7 & $6.25 \%$ \\
\hline $\begin{array}{l}\text { Bank Beirut and Arab Countries } \\
\text { S.A.L }\end{array}$ & BBAC & 7 & $6.25 \%$ \\
\hline Bank Libano-Commercial S.A.L & BLC & 7 & $6.25 \%$ \\
\hline Bank Libano-Française S.A.L & BLF & 7 & $6.25 \%$ \\
\hline BLOM Bank S.A.L & BLOM & 7 & $6.25 \%$ \\
\hline Bank Of Beirut S.A.L & BOB & 7 & $6.25 \%$ \\
\hline Byblos Bank S.A.L & Byblos Bank & 7 & $6.25 \%$ \\
\hline Credit Bank S.A.L & CB & 4 & $3.58 \%$ \\
\hline Credit Libanais S.A.L & CL & 7 & $6.25 \%$ \\
\hline Fenicia Bank S.A.L & Fenicia Bank & 7 & $6.25 \%$ \\
\hline First National Bank S.A.L & FNB & 7 & $6.25 \%$ \\
\hline FRANSABANK S.A.L & Fransabank & 7 & $6.25 \%$ \\
\hline $\begin{array}{l}\text { Intercontinental Bank of } \\
\text { Lebanon S.A.L }\end{array}$ & IBL & 7 & $6.25 \%$ \\
\hline Jammal Trust Bank S.A.L & JTB & 7 & $6.25 \%$ \\
\hline Lebanon and Gulf Bank S.A.L & LGB & 5 & $4.46 \%$ \\
\hline $\begin{array}{l}\text { Middle East and Africa Bank } \\
\text { S.A.L }\end{array}$ & MEAB & 5 & $4.46 \%$ \\
\hline $\begin{array}{l}\text { Société Générale de Banque au } \\
\text { Liban S.A.L }\end{array}$ & SGBL & 7 & $6.25 \%$ \\
\hline Total observations & & 112 & $100 \%$ \\
\hline
\end{tabular}

Table 4: Distribution of Bank-Year observations over the period of 2009 to 2015.

\begin{tabular}{|c|l|c|c|}
\hline \multicolumn{2}{|c|}{} & $\begin{array}{c}\text { Frequency of bank } \\
\text { year observation }\end{array}$ & $\begin{array}{c}\text { \% of bank year } \\
\text { observation }\end{array}$ \\
\hline \multirow{4}{*}{} & 2009 & 14 & $12.5 \%$ \\
\cline { 2 - 4 } & 2010 & 14 & $12.5 \%$ \\
\cline { 2 - 4 } & 2011 & 16 & $14.3 \%$ \\
\cline { 2 - 4 } & 2012 & 17 & $15.2 \%$ \\
\cline { 2 - 4 } & 2013 & 17 & $15.2 \%$ \\
\cline { 2 - 4 } & 2014 & 17 & $15.2 \%$ \\
\hline & 2015 & 17 & $15.2 \%$ \\
\hline & Total & 112 & $100.0 \%$ \\
\hline
\end{tabular}


Table 3 above presents the banks of the study along with their frequency and percentage of observations. Whereas, table 4 above shows the distribution of bankyear observations between 2009 and 2015.

Note that the differences in frequency, percentage of observations (table 3) and percentage of bank-year observations (table 4) are due to the lack of information for all the banks during the period of the study.

\subsection{Data Sources}

The study has used a secondary and unbalanced panel data collected between 2009 and 2015. As a result, the research is based on 112 observations. The data concerning mobile banking application is collected from App Store or Android. However, the data concerning performance, investment in computer software and control variables was extracted from banks' annual reports. Table 5 below represents the secondary data sources.

Table 5: Secondary data sources.

\begin{tabular}{|c|c|c|}
\hline & Definition & Data source \\
\hline Dependent variable & Performance & Banks' annual reports \\
\hline \multirow{2}{*}{$\begin{array}{c}\text { Innovation } \\
\text { variables }\end{array}$} & Mobile banking & App store and android \\
\hline & Investment in computer software & Banks' annual reports \\
\hline Control variables & $\begin{array}{c}\text { Capitalization } \\
\text { Cost Efficiency } \\
\text { Asset Quality } \\
\text { Bank's size } \\
\end{array}$ & Banks' annual reports \\
\hline
\end{tabular}

All ratios used in the study were self-computed using Microsoft Excel.

\subsection{Variables Specification}

Tables 6, 7 and 8 below presents the specification of dependent, independent and control variables respectively. They also provide the significance of each variable along with the previous studies that have used the same specifications. 
Table 6: Dependent variables: Proxies, significance and studies

\begin{tabular}{|c|c|c|c|c|}
\hline Dependent & Indicator & Proxy & Significance & Studies \\
\hline \multirow{2}{*}{ 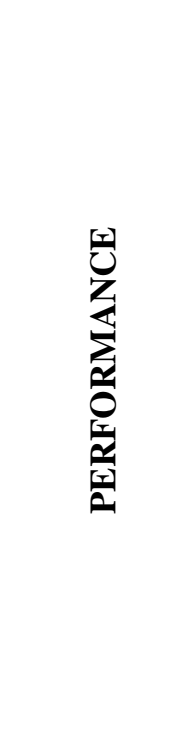 } & $\begin{array}{l}\text { Return- } \\
\text { On- } \\
\text { Assets } \\
\text { (ROA) }\end{array}$ & $\frac{\text { Net income }}{\text { Total asstes }}$ & $\begin{array}{l}\text { Higher ROA } \\
\text { indicates higher } \\
\text { performance. }\end{array}$ & $\begin{array}{l}\text { Beccalli, 2007; Onay et al., } \\
\text { 2008; Jalal-Karim and Hamdan, } \\
\text { 2010; Mwange, 2011; Khrawish } \\
\text { and Al-Sa'di, 2011; Tan and } \\
\text { Floros, 2012; Chronopoulos et } \\
\text { al., 2012; Kithaka, 2014; Saeed, } \\
\text { 2014; Turgutlu, 2014; Akhisar } \\
\text { et al., 2015; Sujud and Hashem, } \\
\text { 2017. }\end{array}$ \\
\hline & $\begin{array}{l}\text { Return- } \\
\text { On- } \\
\text { Equity } \\
\text { (ROE) }\end{array}$ & $\frac{\text { Net income }}{\text { Total equity }}$ & $\begin{array}{l}\text { Higher ROE } \\
\text { indicates higher } \\
\text { performance. }\end{array}$ & $\begin{array}{l}\text { Beccalli, 2007; Onay et al., } \\
\text { 2008; Jalal-Karim and } \\
\text { Hamdan, 2010; Al-Samadi and } \\
\text { Al-Wabel, 2011; Chronopoulos } \\
\text { et al., 2012; Kithaka, 2014; } \\
\text { Saeed, 2014; Turgutlu, 2014; } \\
\text { Akhisar et al., 2015; Samout, } \\
\text { 2016. }\end{array}$ \\
\hline
\end{tabular}

Table 7: Independent variables: Proxies, significance and studies

\begin{tabular}{|c|c|c|c|c|}
\hline $\begin{array}{l}\text { Indepe } \\
\text {-ndent }\end{array}$ & Indicator & Proxy & Significance & Studies \\
\hline \multirow[t]{2}{*}{ 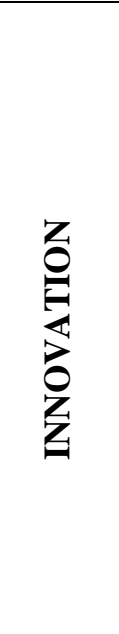 } & $\begin{array}{l}\text { Mobile } \\
\text { banking } \\
(\mathrm{MB})\end{array}$ & $\begin{array}{l}\text { Dummy variable: } \\
-0 \text { if there is no MB } \\
-1 \text { if there is } \mathrm{MB}\end{array}$ & $\begin{array}{l}\text { If the bank has no } \\
\text { mobile banking } \\
\text { application }(\mathrm{MB}=0) \text {, it } \\
\text { has a low involvement } \\
\text { in innovation } \\
\text { If the bank has a } \\
\text { mobile banking } \\
\text { application }(\mathrm{MB}=1) \text {, it } \\
\text { has a high } \\
\text { involvement in } \\
\text { innovation }\end{array}$ & $\begin{array}{l}\text { European Central } \\
\text { bank, 2009; Alber, } \\
\text { 2011; Hasan et al., } \\
\text { 2013; Ngumi, 2013; } \\
\text { Muiruri and Ngari, } \\
\text { 2014; Kashmari et } \\
\text { al., } 2016 .\end{array}$ \\
\hline & $\begin{array}{l}\text { Investment } \\
\text { in computer } \\
\text { software } \\
\text { (ICS) }\end{array}$ & $\begin{array}{l}\text { Ln (intangibles } \\
\text { other than goodwill) }\end{array}$ & $\begin{array}{l}\text { Higher ICS indicates } \\
\text { higher investment in } \\
\text { innovation }\end{array}$ & Stoica et al., 2015. \\
\hline
\end{tabular}


Table 8: Control variables: Proxies, significance and studies

\begin{tabular}{|c|c|c|c|c|}
\hline Control & Indicator & Proxy & Significance & Studies \\
\hline \multirow{5}{*}{ 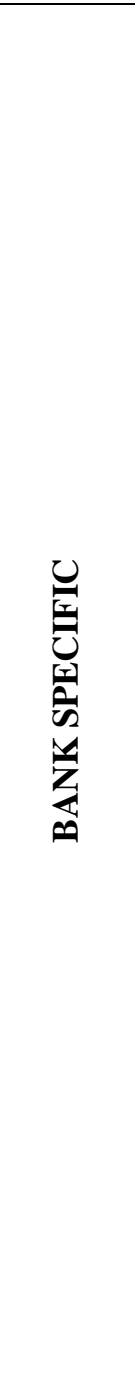 } & $\begin{array}{l}\text { Liquidity } \\
\left(\mathrm{L}_{1}\right)\end{array}$ & $\frac{\text { Total loans }}{\text { Total asstes }}$ & $\begin{array}{l}\text { Higher L1 ratio } \\
\text { indicates lower } \\
\text { liquidity }\end{array}$ & $\begin{array}{c}\text { Sufian and } \\
\text { Habibullah, 2009; } \\
\text { Gul et al., 2011; } \\
\text { Lee,2012; Francis, } \\
\text { 2013; Trujillo- } \\
\text { Ponce, } 2013 .\end{array}$ \\
\hline & $\begin{array}{l}\text { Capitalizati } \\
\text { on (CAR) }\end{array}$ & $\frac{\text { Total equity }}{\text { Total asstes }}$ & $\begin{array}{c}\text { Higher CAR } \\
\text { indicates higher } \\
\text { bank's } \\
\text { capitalization }\end{array}$ & $\begin{array}{c}\text { Athanasoglou et } \\
\text { al., 2005; Ben } \\
\text { Naceur and } \\
\text { Goaied, 2008; } \\
\text { Flamini } \text { et al., } \\
\text { 2009; Dietrich and } \\
\text { Wanzenried, } \\
\text { 2011; Francis, } \\
\text { 2013. }\end{array}$ \\
\hline & $\begin{array}{l}\text { Efficiency } \\
\text { (EFF) }\end{array}$ & $\begin{array}{l}\text { cost to income ratio } \\
=\frac{\text { operating expenses }}{\text { operating income }}\end{array}$ & $\begin{array}{c}\text { Higher EFF } \\
\text { indicates lower cost } \\
\text { efficiency }\end{array}$ & $\begin{array}{l}\text { Heffernan and Fu, } \\
\text { 2008; Dietrich and } \\
\text { Wanzenried, } \\
\text { 2011; Francis, } \\
\text { 2013; Trujillo- } \\
\text { Ponce, 2013. }\end{array}$ \\
\hline & $\begin{array}{l}\text { Asset } \\
\text { quality (AQ) }\end{array}$ & $\frac{\text { Nonperforming loans }}{\text { Total loans }}$ & $\begin{array}{c}\text { Higher AQ } \\
\text { indicates lower } \\
\text { asset quality } \\
\end{array}$ & $\begin{array}{c}\text { Lee, 2012; Macit, } \\
\text { 2012; Trujillo- } \\
\text { Ponce, } 2013 . \\
\end{array}$ \\
\hline & $\begin{array}{l}\text { Bank's size } \\
\text { (SIZE) }\end{array}$ & Ln(Total Assets) & $\begin{array}{l}\text { Higher SIZE } \\
\text { indicates higher } \\
\text { bank's size }\end{array}$ & $\begin{array}{c}\text { Athanasoglou et } \\
\text { al., 2005; Gul et } \\
\text { al., 2011; Macit, } \\
\text { 2012; Tan and } \\
\text { Floros, 2012; } \\
\text { Trujillo-Ponce, } \\
\text { 2013; Saeed, } \\
\text { 2014; Turgutlu, } \\
\text { 2014. }\end{array}$ \\
\hline
\end{tabular}

\subsection{Analysis Techniques}

In order to determine the relationship between innovation and performance in Lebanese banking sector, a quantitative method to data analysis was used. The data was analyzed using a variety of statistical techniques performed through SPSS version 21.0 program. These techniques include descriptive statistics and multiple regression analysis. In order to perform the multiple regression analysis, there is a necessity to conduct various tests for the Classical Linear Regression Model (CLRM) assumptions.

The following 2 models were used in order to determine the cause and effect relationship between bank's performance and innovation: 
$R O A i, t=\alpha+\beta_{1} M B_{i, t}+\beta_{2} I C S_{i, t}+\beta_{3} C A R_{i, t}+\beta_{4} E F F_{i, t}+\beta_{5} A Q_{i, t}+\beta_{6} S I Z E_{i, t}+\varepsilon$

$R O E i, t=\alpha+\beta_{1} M B_{i, t}+\beta_{2} I C S_{i, t}+\beta_{3} C A R_{i, t}+\beta_{4} E F F_{i, t}+\beta_{5} A Q_{i, t}+\beta_{6} S I Z E_{i, t}+\varepsilon$

Where:

- "ROA" and "ROE" : performance in bank " $i$ " for period " $t$ ".

- $\quad \alpha "$ : Y-intercept.

- " $\beta_{i} "$ : coefficient of variable where " $i$ " ranges from 1 to 6 .

- "MB $B_{i, t}$ " : mobile banking in bank " $i$ " for period " $t$ ".

- $\quad I C S_{i, t}$ " : investment in computer software in bank " $i$ " for period " $t$ ".

- $C A R_{i, t}$ " : capitalization in bank " $i$ " for period " $t$ ".

- $\quad E F F_{i, t}$ " : cost efficiency in bank " $i$ " for period " $t$ ".

- " $A Q_{i, t}$ " : asset quality in bank " $i$ " for period " $t$ ".

- $" S I Z E_{i, t}$ " : size of bank " $i$ " in period " $t$ ".

- $" \varepsilon "$ : error term.

\section{Results and Discussion}

The results of the analysis techniques performed are presented thereafter. First, the descriptive statistics is showed. Second, the Classical Linear Regression Model assumptions (CLRM) are tested. Finally, the regression results are presented and discussed.

\subsection{Descriptive Statistics}

The descriptive statistics are performed in order to gain a preliminary understanding of banks' characteristics enrolled in the sample. The focus of this research is mainly on the mean, which measures the central tendency, and the standard deviation, which measures the dispersion. Table 9 below shows the descriptive statistics based on 112 observations. It shows the following: 
Table 9: Descriptive Statistics

\begin{tabular}{|c|c|c|c|c|c|}
\hline & N & Min. & Max. & Mean & $\begin{array}{c}\text { Std. } \\
\text { Deviation }\end{array}$ \\
\hline MB & 112 & 0 & 1 & .35 & .479 \\
\hline ICS & 112 & .0000 & 11.1096 & 5.4627 & 3.3457 \\
\hline CAR & 112 & .0496 & .1232 & .0849 & .0128 \\
\hline EFF & 112 & 31.7000 & 83.8000 & 53.1040 & 11.6287 \\
\hline AQ & 112 & .0010 & .2128 & .0335 & .0399 \\
\hline SIZE & 112 & 13.0982 & 17.5595 & 15.5658 & 1.1031 \\
\hline ROA & 112 & .0017 & .0162 & .0096 & .0026 \\
\hline ROE & 112 & .0182 & .1859 & .1153 & .0324 \\
\hline Valid N & 112 & & & & \\
(listwise) & & & & & \\
\hline
\end{tabular}

Mobile banking (MB) has a mean of 0.35 , which implies that on average $35 \%$ of banks in the sample have a mobile banking application. However, the large standard deviation (0.479) shows that there are large dispersions in the sample.

Natural logarithm of the investment in computer software (ICS) has a mean of 5.4627. This shows that Lebanese banks spend on average 235,599 $\mathrm{USD}^{2}$ on their computer software. The standard deviation is large (3.3457).

Capitalization (CAR) has a mean of 0.0849. It indicates that equity represents on average $8.49 \%$ of total assets. So, Lebanese banks are well-capitalized. They are more capitalized than Chinese banks where equity to assets is equal to $5.1 \%$ (Tan and Floros, 2012). However, they are less capitalized than Sub-Saharan Africa (SSA) banks where equity to assets ratio is equal to $12.55 \%$ (Flamini et al., 2009). The standard deviation (0.0128) shows a low dispersion in the sample.

Cost efficiency (EFF) has a mean value of 53.1040. This shows that on average operating costs constitutes $53.1040 \%$ of operating revenues. It is less than the average cost-to-income in Spanish banking sector (57.337\%) (Trujillo-Ponce, 2013) and in Sub-Saharan Africa banking sector (62.98\%) (Francis, 2013). Since a higher cost-to-income ratio indicates a less efficiency, Lebanese banks are more efficient than both Spanish and Sub-Saharan Africa banks. However, the standard deviation has an average value of 11.6287 .

Asset quality (AQ) has a mean of 0.0335 which indicates that on average nonperforming loans constitutes $3.35 \%$ of total customers' loans. This reflects a good AQ situation in Lebanese banks compared to banks in other countries. For example, in Spanish banking sector, the ratio of nonperforming loans to total loans is equal to 1.536 (Trujillo-Ponce, 2013) which is higher than that of Lebanese banks. Since

${ }^{2}$ Since we are considering the natural logarithm of the investment in computer software, thus the amount spent on this software is equal to $e^{5.4627}=235.599$ thousands USD. 
higher nonperforming loans to total loans ratio indicates a poor asset quality, Lebanese banks have a better asset quality than Spanish banks. In addition, there is a large dispersion in the sample reflected by a high standard deviation (0.0399).

Bank's size (SIZE), which is the natural logarithm of bank's total assets, has a mean value of 15.5658. So, Lebanese banks are larger than both US (11.6) and Turkish (3.496) banks as found respectively by Hoffmann (2011) and Turgutlu (2014). In addition, the standard deviation has a value of 1.1031. This reflects that there is a little dispersion in the sample ${ }^{3}$

Return-On-assets (ROA) has a mean of 0.0096, which reflects that on average Lebanese banks get $0.96 \$$ of profits for every $1 \$$ invested in total assets. The average ROA in Lebanese banks is higher than that in US (0.79\%) (Chronopoulos et al., 2012) and Tunisian banks (0.6\%) (Ben Naceur and Goaied, 2008). Plus, the standard deviation value is equal to 0.0026 , which reflects a dispersion in the sample. Return-On-Equity (ROE) has a mean of 0.1153 , which shows that on average Lebanese banks get $11.53 \$$ for every $1 \$$ invested in shareholders' equity. However, the average ROE in both Turkish (0.1704) (Topak and Talu, 2017) and in US (0.20256) (Hoffmann, 2011) banking sectors are higher than that in Lebanese banking sector. Moreover, the standard deviation has a value of 0.0324 indicating a high dispersion.

\subsection{Classical Linear Regression Model (CLRM) Assumptions}

Before going further into regression analysis, it is essential to test the assumptions of the CLRM. According to Saunders et al. (2009), there are four main assumptions for regression analysis:

- Absence of heteroscedasticity

- Absence of autocorrelation

- Absence of multicollinearity

- Presence of normal distribution

First, the heterogeneity of variance also called heteroscedasticity. It is the extent to which dependent and independent data do not have equal variances. In order to test heteroscedasticity, a Koenker test is performed for the two models. Table 10 below shows the results of Koenker test for both models.

3 The mean and standard deviation values were almost expected since thirteen (13) out of seventeen (17) banks in the sample are from the largest banks in Lebanon (Alpha banks). 
Table 10: Koenker Test.

\begin{tabular}{|c|c|c|}
\hline Models & LM & P-value \\
\hline 1 (dependent: ROA) & 23.507 & $.001^{*}$ \\
\hline 2 (dependent: ROE) & 26.281 & $.000^{*}$ \\
\hline (*) significant at 5\% & \\
\hline
\end{tabular}

The null hypothesis for this test assumes that there is no heteroscedasticity. If the test shows a significant P-value (less than 0.05), so there is a rejection of the nullhypothesis. Based on table 10 above, both models have significant p-values. As a result, there is heteroscedasticity and we should reject the null hypothesis.

Second, autocorrelation refers to the situation where dependent variable at time " $t$ " is related to its value at "t-1" (Saunders et al., 2009). Durbin Watson Statistic is applied below (table 11) in order to test autocorrelation.

Table 11: Durbin Watson (DW) Statistic.

\begin{tabular}{|c|c|}
\hline Models & DW \\
\hline 1 (dependent: ROA) & 1.083 \\
\hline 2 (dependent: ROE) & 1.043 \\
\hline
\end{tabular}

Absence of autocorrelation is observed when DW is near 2 (Saunders et al., 2009). Accordingly, there is autocorrelation in both models.

To overcome heteroscedasticity and autocorrelation issues, a Weighted Least Squares model should be used (Brooks, 2008).

Third, multicollinearity means the absence of correlation between independent variables. It is tested by the Variance Inflation Factor (VIF), tolerance and Pearson Product Moment Correlation Coefficient test.

Table 12: VIF and Tolerance test.

\begin{tabular}{|c|c|c|c|}
\hline \multicolumn{2}{|c|}{ Model } & \multicolumn{2}{c|}{ Collinearity Statistics } \\
\cline { 3 - 4 } \multicolumn{1}{|c|}{} & Tolerance & VIF \\
\hline \multirow{4}{*}{$1 \& 2$} & MB & .810 & 1.234 \\
\cline { 2 - 4 } & ICS & .793 & 1.261 \\
\cline { 2 - 4 } & CAR & .893 & 1.119 \\
\cline { 2 - 4 } & EFF & .681 & 1.469 \\
\cline { 2 - 4 } & AQ & .719 & 1.390 \\
\cline { 2 - 4 } & SIZE & .423 & 2.366 \\
\hline
\end{tabular}


Table 12 above shows the results for both VIF and tolerance tests in model 1 and $2^{4}$. The absence of multicollinearity is observed when VIF has a value of less than 10 and tolerance has a value of more than 0.1 (Saunders et al., 2009). So, there is no multicollinearity between independent variables.

Table 13: Multicollinearity Matrix.

\begin{tabular}{|l|r|r|r|r|r|r|r|r|}
\hline & \multicolumn{1}{|c|}{ MB } & \multicolumn{1}{c|}{ ICS } & CAR & \multicolumn{1}{c|}{ EFF } & \multicolumn{1}{c|}{ AQ } & SIZE & ROA & ROE \\
\hline MB & 1 & & & & & & & \\
\hline ICS & .110 & 1 & & & & & & \\
\hline CAR & $.203^{*}$ & -.006 & 1 & & & & & \\
\hline EFF & $-.215^{*}$ & -.143 & -.065 & 1 & & & & \\
\hline AQ & -.064 & .013 & .123 & $.302^{* *}$ & 1 & & & \\
\hline SIZE & $.399^{* *}$ & $.382^{* *}$ & .173 & $-.557^{* *}$ & $-.431^{* *}$ & 1 & & \\
\hline ROA & .037 & $.254^{* *}$ & $.206^{*}$ & $-.504^{* *}$ & $-.205^{*}$ & $.346^{* *}$ & 1 & \\
\hline ROE & -.084 & $.257^{* *}$ & $-.304^{* *}$ & $-.467^{* *}$ & $-.238^{*}$ & $.231^{*}$ & $.857^{* *}$ & 1 \\
\hline
\end{tabular}

Table 13 above shows the result of Pearson Product Moment Coefficient test. According to Saunders et al. (2009), the "r" value of the test should be less than $|0.9|$ to avoid multicollinearity. Therefore, there is no multicollinearity between the variables.

Table 14: Skewness and Kurtosis tests.

\begin{tabular}{|l|c|c|c|}
\hline & $\mathbf{N}$ & Skewness Statistic & Kurtosis Statistic \\
\hline MB & 112 & .646 & -1.612 \\
\hline ICS & 112 & -.637 & -.941 \\
\hline CAR & 112 & .654 & 1.007 \\
\hline EFF & 112 & .850 & .631 \\
\hline AQ & 112 & 2.393 & 6.504 \\
\hline SIZE & 112 & -.285 & -.703 \\
\hline ROA & 112 & -.100 & .588 \\
\hline ROE & 112 & .020 & .417 \\
\hline Valid N (listwise) & 112 & & \\
\hline
\end{tabular}

Finally, to guarantee data normality, two tests were performed: skewness and kurtosis. Both tests' values should be within -1 and +1 . Based on table 14 above, which presents the results of normality tests, we can conclude that mobile banking,

${ }^{4}$ The results of both VIF and tolerance tests are the same for both models. So, they were combined in table 12 . 
capitalization and asset quality are not normally distributed.

However, "the assumption of normality could be ignored without incurring too many problems especially when the number of observation is higher than 30" (Saunders et al., 2009, pp. 457, 459). Consequently, normality assumption is ignored.

\subsection{Regression Results and Discussion}

In order to assess the relationship between innovation and bank's performance, a Weighted Least Squares (WLS) regression analysis is performed. The results of the WLS for model 1 and 2 are represented in table 15 below. This table shows that both models are highly significant since p-value is equal to 0.000 . Adjusted Rsquares for models 1 and 2 are respectively $61.3 \%$ and $71.8 \%$. This means that $61.3 \%$ of variations in ROA and $71.8 \%$ of variations in ROE are explained by the variables studied.

Beta coefficients for Mobile Banking (MB) with both ROA and ROE are negative (-0.119 and -0.136 respectively). This indicates a negative effect of MB on performance. Mobile banking needs large investment and has low-income margins (Sujud and Hashem, 2017). Moreover, MB has a high perceived risk and low confidentiality (Alber, 2010). This finding contradicts Mwange (2011) and Kithaka (2014) results, since they have found a positive association between MB and performance in Kenyan and Nigerian banking sectors respectively. Moreover, contrary to Solow paradox theory contribution, MB has showed a highly significant relation with both ROA and ROE at $1 \%$ level of significance. Hypothesis 1, which expects a positive and significant effect of MB on bank's performance, should be rejected.

Beta coefficients of investment in computer software (ICS) are equal to 0.361 and 0.345 with ROA and ROE respectively. So, ICS has a positive impact on banking performance. It has also a highly significant (at $1 \%$ level of significance) association with it. This contradicts the Solow paradox and the contributions of Licht and Moch, (1999), Beccalli (2007) and Oluwagbemi et al. (2011). However, it emphasizes the results of Prasad and Harker (1997), Chen and Zu (2004) and Ben Romdhane (2013). Higher investment in computer software leads to easier and faster transactions and higher customer care. As a result, banks will attract more potential customers and will perform better. Hypothesis 2 , which expects a significant positive effect of ICS on performance, should be accepted.

Beta coefficient of Capitalization (CAR) was found to be positive (0.166) with ROA but negative with ROE. These findings are not contradictory. Mathematically, an increase of equity to asset ratio is due to either an increase in equity or a decrease in assets. All things being equal, when assets are decreased, both CAR and ROA increase. As a result, a positive impact of CAR on ROA is shown. However, when equity increases all things being equal, CAR will increase while ROE will decrease. This indicates a negative impact of CAR on ROE. Moreover, it was found that CAR has a statistically significant impact on both ROA and ROE (at $1 \%$ level). 
Beta coefficient of cost efficiency (EFF) in both models was found negative $(-0.560$ with ROA and -0.558 with ROE). However, as previously mentioned cost-toincome ratio should be interpreted inversely since it indicates inefficiency. Accordingly, EFF has a positive and highly significant (at $1 \%$ level of significance) impact on performance as measured by both ROA and ROE.

Although beta coefficient of asset quality (AQ) in both models was found positive ( 0.074 and 0.056 with ROA and ROE respectively), they must be interpreted as being negative since asset quality is measured by NPL over total loans, and thus, by its inverse. It has been also found that AQ has a statistically insignificant impact on both bank's performance variables.

Table 15: WLS results for models $1 \& 2$

\begin{tabular}{|c|c|c|c|c|}
\hline & \multicolumn{2}{|c|}{$\begin{array}{c}\text { Model 1: dependent } \\
\text { variable ROA } \\
\text { (net income to total assets) }\end{array}$} & \multicolumn{2}{|c|}{$\begin{array}{c}\text { Model 2: dependent } \\
\text { variable ROE } \\
\text { (net income to total equity) }\end{array}$} \\
\hline & $\begin{array}{l}\text { Standardized } \\
\text { Coefficients }\end{array}$ & Sig. & $\begin{array}{l}\text { Standardized } \\
\text { Coefficients }\end{array}$ & Sig. \\
\hline & Beta & & Beta & \\
\hline (Constant) & & $.002 * * *$ & & $.000 * * *$ \\
\hline $\mathrm{MB}$ & -.119 & $.062 *$ & -.136 & $.013 * *$ \\
\hline ICS & .361 & $.000 * *$ & .345 & $.000 * * *$ \\
\hline CAR & .166 & $.010 * * *$ & -.415 & $.000 * * *$ \\
\hline EFF & -.560 & $.000 * * *$ & -.558 & $.000 * * *$ \\
\hline $\mathrm{AQ}$ & .074 & .257 & .056 & .320 \\
\hline SIZE & .122 & $.092 *$ & .083 & .175 \\
\hline R-square & \multicolumn{2}{|c|}{$63.4 \%$} & \multicolumn{2}{|c|}{$73.3 \%$} \\
\hline Adjusted R-square & \multicolumn{2}{|c|}{$61.3 \%$} & \multicolumn{2}{|c|}{$71.8 \%$} \\
\hline F statistic & \multicolumn{2}{|c|}{30.299} & \multicolumn{2}{|c|}{48.139} \\
\hline Model significance P-value & \multicolumn{2}{|c|}{.000} & \multicolumn{2}{|c|}{.000} \\
\hline \multicolumn{5}{|c|}{ Levels of significance: $(* * *) 1 \%,(* *) 5 \%$ and $(*) 10 \%$} \\
\hline \multicolumn{5}{|c|}{$\begin{array}{l}\text { Note that: higher EFF ratio and higher AQ imply respectively lower efficiency and lower } \\
\text { asset quality, so the results of beta coefficient for these two variables should be inversely } \\
\text { interpreted. }\end{array}$} \\
\hline
\end{tabular}

Bank's size (SIZE) was found to have a positive impact on ROA (beta coefficient is equal to 0.122) and on ROE (beta coefficient is equal to 0.083). However, it was only found significant with ROA at $10 \%$ level of significance.

Table 16 below provides a summary of hypotheses rejection for both ROA and ROE. 
Table 16: Hypotheses rejection for Model 1 (dependent: ROA) \& 2 (dependent: ROE).

\begin{tabular}{|c|c|c|c|c|c|}
\hline Hypot-hesis & Variable & $\begin{array}{c}\text { Expected } \\
\text { relationship }\end{array}$ & $\begin{array}{c}\text { Actual } \\
\text { relationship } \\
\text { (model 1) }\end{array}$ & $\begin{array}{c}\text { Actual } \\
\text { relationship } \\
\text { (model 2) }\end{array}$ & Rejection \\
\hline $\mathrm{H} 1$ & $\mathrm{MB}$ & $+\&$ sig. & $\begin{array}{c}-\& \text { sig at } \\
10 \%\end{array}$ & $\begin{array}{c}-\& \text { sig. at } \\
5 \%\end{array}$ & Rejected \\
\hline $\mathrm{H} 2$ & $\mathrm{ICS}$ & $+\&$ sig. & $\begin{array}{c}\text { \& sig. at } \\
1 \%\end{array}$ & $\begin{array}{c}\text { \& sig. at } \\
1 \%\end{array}$ & $\begin{array}{c}\text { Not } \\
\text { rejected }\end{array}$ \\
\hline \multicolumn{7}{|l}{ Note: Sig: significant, Insig: insignificant }
\end{tabular}

\section{Conclusion}

Innovation severely affects banking sector, it is expected to destroy the models used in developing and delivering services and replace them with new and original ones (DeYoung, 2001). Examining the impact of innovation on bank's performance is crucial for many stakeholders. Using data of 17 Lebanese owned commercial banks from 2009 to 2015, this research focuses on the impact of mobile banking (MB) and investment in computer software (ICS) on the performance of Lebanese banks. Four control variables were also included in the study namely capitalization (CAR), cost efficiency (EFF), asset quality (AQ) and size (SIZE). Banking performance is measured by two ratios, Return-On-Assets (ROA) and Return-On-Equity (ROE). A weighted Least Squares estimation method was applied to avoid heteroscedasticity and autocorrelation issues.

The results of both models were similar, significant variables were mobile banking (MB), investment in computer software (ICS), capitalization (CAR) and cost efficiency (EFF). Bank's Size (SIZE) was only found significant with ROA. Asset quality has failed to prove any significance at any level. The direction of relationships between the significant independent variables and both ROA and ROE are the same in both models. The only difference was in the direction of capitalization that was positive with ROA and negative with ROE.

The results of the study are exploratory due to two main limitations related to sample size, type of data and choice of variables. First, data was collected from only $53.13 \%$ of "Lebanese owned banks" since the data of both the remaining $46.87 \%$ "Lebanese owned banks" and the other groups is unpublished electronically. Second, the data collected was only in a consolidated form taken from consolidated financial statements over 7 years' period for each bank. Third, the list of banking innovations included in the study is not exhaustive. There may be other factors that could be included and consequently, this may alter the results of the study.

We should note that current research might be extended in various directions by: increasing the sample size, measuring performance using other than ROE and ROA such as profit before tax, margin and net interest margin and testing the effect of other innovations on bank's performance (number of credit and debit cards, number of POS terminals, number of ATMs). 


\section{References}

[1] Abaenewe, Z.C., Ogbulu, O.M and Ndugbu, M.O. (2013). Electronic Banking and Bank Performance in Nigeria. West African Journal of Industrial \& Academic Research, Vol. 6, No.1, pp.171-187.

[2] Akhisar, I., Tunayb, K.B. and Tunaya, N. (2015). The Effects of Innovations on Bank Performance: The Case of Electronic Banking Services. Procedia Social and Behavioral Sciences. pp. $369-375$.

[3] Alber, N. (2010). The effect of banking expansion on profit efficiency of Saudi banks. Second International Conference on Business and Economic Research (2nd ICBER 2011) Proceeding 269. Available at: https://www.researchgate.net/publication/227439499

[4] Al-Samadi, M. and Al-Wabel, S. (2011). The impact of E- banking on the performance of Jordanian banks. Journal of Internet Banking and Commerce. Vol. 16, No. 2, pp. 1-10.

[5] Association of Banks in Lebanon. (2014). Annual report edition 2014. Available at: http://www.abl.org.lb/subPage.aspx?pageid=9478

[6] Athanasoglou, P., Brissimis, S. and Delis, M. (2005). Bank-specific, industryspecific and macroeconomic determinants of bank profitability. Bank of Greece Working Paper No. 25. pp. 1-32.

[7] BCG, Boston Consulting Group. (2009). BCG Innovation 2009 Report.

[8] Beccalli, E. (2007). Does IT investment improve bank performance? Evidence from Europe. Università Degli Studi Di Macerata.

[9] Ben Naceur, S. and Goaied, M. (2008). The determinants of commercial bank interest margin and profitability: Evidence from Tunisia. Frontiers in Finance and Economics. Vol. 5, No.1, pp. 106- 130.

[10] Ben Romdhane, S. (2013). Impact of information technology on the performance of Tunisian banks: A stochastic frontier analysis with panel data. Asian academy of management journal of accounting and finance, Vol. 9, No. 2, pp. 95-125.

[11] BLOMINVEST BANK. (2016). Hurdles of Digital Banking in Lebanon. Available at: https://blog.blominvestbank.com/15923/hurdles-of-digitalbanking-in-lebanon/

[12] Brooks, C. (2008). Introductory econometrics for finance. (2nd edn). United Kingdom: Cambridge University Press.

[13] Chen, Y. and Zhu, J. (2004). Measuring Information Technology's indirect impact on firm performance. Information Technology and Management, Vol. 5, pp. 9-22.

[14] Chronopoulos, D., Liu, H., McMillan, F. and Wilson, J. (2012). The dynamics of US Bank profitability. Available at http://ssrn.com/abstract=1972835

[15] DeYoung, R. (2001). The Financial Performance of Pure Play Internet Banks. Economic Perspectives. Vol. 25 No. 1, pp. 60-75. 
[16] Dietrich, A. and Wanzenried, G. (2011). Determinants of bank profitability before and during the crisis: Evidence from Switzerland. Journal of International Financial Markets, Institutions and Money. Doi:10.1016.

[17] European Central Bank. (2009). Return to retail banking and payments. Working paper series, No. 1135 / December 2009.

[18] Flamini, V., McDonald, C. A. and Schumacher, L. (2009). The determinants of commercial bank profitability in Sub-Saharan Africa (EPub). International Monetary Fund. Vol. 9.

[19] Francis, M. E. (2013). Determinants of commercial bank profitability in SubSaharan Africa. International Journal of Economics \& Finance. Vol. 5, No. 9, pp. 134-147.

[20] Gul, S., Irshad, F. and Zaman, K. (2011). Factors affecting bank profitability in Pakistan. The Romanian Economic Journal. Vol. 14, pp. 61-87.

[21] Hasan, Mamman, and Farouk. (2013). Electronic banking products and performance of Nigerian listed deposit money banks. American Journal of Computer Technology and Application Vol. 1, No.10, pp. 138-148.

[22] Jalal-Karim, A. and Hamdan, A.M. (2010). The impact of information technology on improving banking performance matrix: Jordanian banks as case study. European, Mediterranean \& Middle Eastern Conference on Information Systems 2010, April 12-13 2010, Abu Dhabi, UAE.

[23] Kashmari, A., Nejad, A.H.G., and Nayebyazdi, A. (2016). Impact of Electronic Banking Innovations on Bank Deposit Market Share. Journal of Internet Banking and Commerce. Vol. 21, No. 1, pp. 1-12.

[24] Kathuo, S., Rotich, G. and Anyango, W. (2015) Effect of mobile banking on the financial performance of banking institutions in Kenya. The Strategic Journal of Business and Change Management, Vol. 2, No. 98, pp 1440 - 1457.

[25] Khrawish, A.H. and Al-Sa'di, N.M. (2011). The Impact of E-Banking on Bank Profitability: Evidence from Jordan.

[26] Kithaka, E. (2014). The effect of mobile banking on performance of commercial banks in Kenya. Master's Thesis, University of Nairobi, Nairobi.

[27] Lee, S. W. (2012). Profitability determinants of Korean banks. Economics and Finance Review. Vol. 2, No. 9, pp. 6-18.

[28] Licht, G. and Moch, D. (1999). Innovation and Information Technology in Services. The Canadian Journal of Economics, Vol. 32, No.2, pp. 363-383. Available at: http://www.jstor.org/stable/136427

[29] Macit, F. (2012). Bank specific and macroeconomic determinants of profitability: Evidence from participation banks in Turkey. Economics Bulletin. Vol. 32, No. 1, pp. 586-595.

[30] Markus, L. and Soh, C. (1993). Banking on Information Technology: Converting IT Spending into Firm Performance.

[31] Muiruri, J.K. and Ngari, J.M. (2014). Effects of Financial Innovations on the Financial Performance of Commercial Banks in Kenya. International Journal of Humanities and Social Science. Vol. 4, No. 7, pp. 51-57. 
[32] Mutua, R. (2013). The effects of mobile banking on the financial performance of commercial banks in Kenya. MBA Thesis, University of Nairobi, Nairobi.

[33] Mwange, J.A. (2013). The impact of mobile banking on financial performance of commercial banks in Kenya. Master's Thesis, University of Nairobi, Nairobi.

[34] Ngumi, P.M. (2013). Effect of bank innovations of financial performance of commercial banks in Kenya. Ph.D Thesis, JOMO Kenyatta University of Agriculture and Technology, Kenya.

[35] Oluwagbemi, O., Abah, J. and Achimugu, P. (2011). The impact of Information Technology in Nigeria's banking industry. Journal of Computer Science and Engineering, Vol. 7, No. 2, pp. 63-67.

[36] Prasad, B. and Harker, P. T. (1997). Examining the contribution of information technology toward productivity in US retail banking. (Working paper), Wharton School, University of Pennsylvania.

[37] Saeed, M. S. (2014). Bank-related, industry-related and macroeconomic factors affecting bank profitability: A case of the United Kingdom. Research Journal of Finance and Accounting. Vol. 5, No. 2, pp. 42-50.

[38] Samout, A. (2016). Innovation and performance of Tunisian banks. International Journal of Economics, Finance and Management Sciences, Vol. 4, No. 2, pp. 87-92. Available at: http://www.sciencepublishinggroup.com/j/ijefm

[39] Sarji, M.A. (2017). Information Technology and its influence on the Lebanese banking sector. Journal of Business and Management, Vol. 19, No. 4, pp. 1928.

[40] Saunders, M. and Lewis, P. and Thornhill, A. (2009). Research methods for business students. ( $5^{\text {th }}$ edn). England: Pearson Education Limited.

[41] Solow, R. (1987). We'd better watch out. New York Times Book Review, p. 36.

[42] Stoica, O., Mehdian, S. and Sargu, A. (2015). The impact of internet banking on the performance of Romanian banks: DEA and PCA approach. Procedia Economics and Finance. Vol. 20, pp. $610-622$.

[43] Sufian, F., and Habibullah, M. S. (2009). Determinants of bank profitability in a developing economy: Empirical evidence from Bangladesh. Journal of Business Economics and Management. Vol. 10, No.3, pp. 207-217.

[44] Sujud, H. and Hashem, B. (2017). Effect of bank innovations on profitability and return on assets (ROA) of commercial banks in Lebanon. International Journal of Economics and Finance, Vol. 9, No. 4, pp. 35-50.

[45] Tiwari, R. Buse, S and Herstatt, C. (2006) Mobile Banking as Business Strategy: Impact of Mobile Technologies On Customer Behaviour and Its Implications for Banks. Working Paper No. 37. Presented at Technology Management for the Global Future - Proceedings of PICMET.

[46] Trujillo-Ponce, A. (2013). What determines the profitability of banks? Evidence from Spain. Accounting \& Finance. Vol. 53, pp. 561-586. 
[47] Turgutlu, E. (2014). Dynamics of profitability in the Turkish banking industry. Ege Academic Review. Vol. 14, No.1, pp. 43-52.

[48] World Bank. (2017). Data: Lebanon. Available at:

https://data.worldbank.org/country/lebanon 